\title{
Building capacity and continuous improvement of school libraries: The Delaware experience
}

\author{
Dr Ross J Todd \\ Associate Professor \\ Rutgers, The State University of New Jersey \\ New Brunswick New Jersey \\ USA
}

\begin{abstract}
This research paper is in two parts. "Part I: The Evidence" documents the background, purpose, methodology and findings of the Delaware School Library Infrastructure Study undertaken on behalf of the Delaware Governor's Task Force, and highlights some key issues and concerns that have formed the basis for . "Part 2: From Evidence to Action" documents the processes and professional actions involved in developing a sustainable program of improvement for school libraries in Delaware through engaging with the research evidence. This research and development process, initiated in 2005, is an ongoing evidence-based practice program engaging multiple partnerships at school district and state department of education to focus on continuous improvement and capacity building of school libraries in the state of Delaware. At its center is a process of engaging school librarians in a research-based, data-driven cycle of transforming school libraries so that they can play a central and identifiable role in curriculum implementation, student achievement, reading, and literacy development in Delaware's schools, and to ensure that Delaware's school libraries play a role in world class learning and literacy in the state.
\end{abstract}

Evidence Based Practice, School Library Research, Delaware School Libraries

\section{Background: Delaware Context and the Governor's Task Force on School Libraries}

The Governor's Task Force on School Libraries was first convened by state Governor Thomas R. Carper in 1993, to improve and extend the library and information services for Delaware's K-12 students. In 2003 Governor Ruth Ann Minner reconstituted the Task Force and commissioned it to be engaged in the following activities:

- Close communication and shared activities with the Department of Education, through the Education Associate for Library/media/Technology;

- Developing collaboration among school and public libraries, as well as with college and university libraries, working through the Delaware Division of Libraries;

- Encouraging the use of Standards for Library Media Centers, Delaware Public Schools by district and schools to assess and improve their programs;

- Conducting an annual survey to gather data about Delaware school libraries;

- Involvement with literacy efforts throughout the State, especially reading initiatives 
in the schools; and

- Support the Exemplary School Library Project to showcase the effects on academic achievement of a quality elementary school library.

In 2005, the Center for International Scholarship in School Libraries at Rutgers University (CISSL) was formally engaged to first undertake the annual survey as required in the Governor's brief, and second, to examine and document exemplary school libraries' contributions to academic achievement in the state. The first study is reported here. While various constituencies in Delaware had collected data for several years to provide first-hand information to schools, districts, and interested political and educational groups, this data were not complete in analysis nor findings, and little use was made of it.

A review of these earlier instruments also indicated some potential limitations in providing data that would ultimately serve to highlight the contribution of Delaware school libraries to learning achievement. For example, while the survey collected important data regarding the physical and personnel infrastructure of the school library - data related to staffing levels, resource levels, information technology infrastructure, and fiscal support levels - there was no direct input from the school librarians on the nature of their instructional role, their information literacy initiatives, nor any perceptions of how this instructional role impacted on student achievement. It was felt that the surveys previously used needed to be extended to encompass these dimensions.

\section{Part I: The Evidence Conceptual Framework for the Study}

The conceptual framework used for structuring the survey instrument was based on the model of the School Library as a Dynamic Agent of Learning, developed by Todd and Kuhlthau (2005). This model, underpinned by an extensive body of school library research extending over three decades (see for example, Scholastic's synthesis of research in School Libraries Work!), was explicitly based on quantitative and qualitative data collected from 13,123 students and 870 teaching faculty in 39 schools across Ohio. The model posits that as a dynamic agent of learning, a school library's intellectual and physical infrastructure centers on three essential interactive and iterative components: informational (the information resource and information technology infrastructure; transformational (the instructional interventions and student engagement initiatives), and formational (learning impacts and student outcomes). Central to this dynamic process are certified school librarians and support staff who lead and enable the school library to meets its learning objectives. These components are shown in the model below: 


\section{Figure 1 \\ Model of the School Library as a Dynamic Agent of Learning}



Also guiding this study was a professional need for capacity building and continuous improvement of school libraries. In this context, capacity building is broadly conceptualized as any process, strategy, initiative or action that is employed to strengthen or facilitate the ability of school libraries to provide powerful and sustainable, high quality in their schools, and to provide opportunities for school teams to work together in new ways (Noah \& Brickman, 2004; Harris \& Lambert, 2003).

Accordingly, the revised survey instrument sought to capture not just data related to the physical, resource and personnel infrastructure, but to gain initial perceptions into the nature and focus of instructional activities of school librarians, initiatives related to fostering the development of reading through the school library, as well as some insight into what the school librarians perceive to be the impact of the school library on student learning outcomes and achievement.

This holistic approach to the survey scope represents a key departure in the development of survey instruments to characterize and profile school libraries, which historically have given primary emphasis to informational dimensions, with limited attention to transformational and formational dimensions. This direction was considered timely, particularly in the context of developments in the field of school librarianship, including:

- an increased focus on the role of the school library's contribution to student learning outcomes (Scholastic, 2008);

- the emergence of the evidence-based practice as both an issue and direction for the field (Eldredge, 2000; Todd, 2007);

- the increased focus on quality teaching and learning across the whole school, and the dynamics of productive pedagogy to enable meaningful learning to take place through the school library (Gore \& Ladwig, 2002); 
- a focus on elucidating more carefully the dynamics of instructional intervention through the school library and its relationship to learning outcomes (Kuhlthau et al, 2007);

- The current climate of standards-based education, accountability, performance excellence and school improvement, coupled with pressures of reduced budgets and staffing (Slavin, 2008).

\section{Methodology}

The three dimensions identified above formed the central goals of the research study, which first sought to construct a picture of the status of Delaware's school libraries in terms of their informational-transformational-formational dimensions, and second, to use this as a basis for developing a sustained and long term program of capacity building and evidencebased continuous improvement. Accordingly, the study sought to gather baseline data about the state of Delaware's school libraries in terms of:

(a) extent and levels of staffing, both professional and paraprofessional (support staff);

(b) nature and extent of information resources across multiple formats and their alignment with Delaware's curriculum and their support of state academic content standards;

(c) nature and extent of technology infrastructure, its use and levels of technical support;

(d) reading and literacy initiatives targeted to both informational curriculum needs as well as pleasure/leisure reading;

(e) the range of instructional and curriculum activities that school librarians are involved in at their schools, with specific emphasis on the nature and extent of information literacy initiatives, including technical and digital literacies and the thinking and communication competencies for information access, retrieval, production, and dissemination;

(f) school librarians' engagement in instructional collaborations, co-ordinations and cooperations;

(g) nature and extent of curriculum engagement, professional development within and outside of the school;

(h) perceptions the impact of the school library on student learning outcomes and achievement;

(i) challenges, barriers and enables to professional school library work.

\section{Data Collection and Sample}

Data were collected through a web-based (Zoomerang) survey questionnaire that collected both quantitative and qualitative data. Following development and pilot testing, the survey instrument was made available to school librarians in Delaware, and once collected, it was further analyzed using SPSS, the Statistical Package for the Social Sciences. A copy of the survey instrument is available at: http://www2.lib.udel.edu/taskforce/survey2004.doc. The survey instrument was confidential and not anonymous, as it collected specific data on individual public schools, and this enabled the members of the Delaware Governor's Task to provide any necessary assistance with completing the survey, and to track survey completion and submission. As a result, $100 \%$ of the Delaware public schools - 154 public schools completed the survey, resulting in a comprehensive and robust data set of the informational, transformational and formational dimensions of school libraries across the state. Specifically, 91 elementary, 31 middle, 30 high schools, and 2 composite schools were represented in the study. 


\section{Selected Findings}

It is not intended here to provide a full explication of all findings of this study. A full report is available at: http://www2.lib.udel.edu/taskforce/study/phasetwo.pdf. A snapshot of the informational, transformational and formational landscape of Delaware's public school libraries is presented here, and with focus on the data that have formed the foundation for the program of capacity building and continuous improvement.

\section{Personnel}

$71 \%$ of library employees are state certified school librarians. $18.8 \%$ are school librarians on emergency or limited certificates. The largest group of non-certified school librarians or school librarians on limited certification are in elementary schools. $60 \%$ of school libraries have support staff employed. 54\% of elementary school libraries have no assistant support. Only $22 \%$ of school libraries have full time support staff.

\section{School librarians' engagement in relational activities}

Co-operations (defined as informal communications between teachers and school librarians), rather than co-ordinations (where the teacher and school librarian may meet together to discuss a lesson/unit of study, but where the individual goal setting, learning experience design, teaching, and evaluation are done independently) and collaborations, (defined as the teacher and school librarian jointly setting goals, designing learning experiences, teaching and evaluating a comprehensive unit of study) are the predominant mode of school librarians' interactions with teaching faculty. These primarily take place in English Language Arts, Social Studies and Science, and are typically multiple co-operations over time.

The data on the number of co-ordinations indicate that a significant group of school librarians do not engage in any level of formal (as opposed to the more informal) interactions with teaching faculty in relation to curriculum activities that involve the library. Specifically, $28.5 \%$ of school librarians have no co-ordinations in English Language Arts, 32.5\% of school librarians have no co-ordinations in Social Studies, 39.6\% of school librarians have no coordinations in Science, and $75.3 \%$ of school librarians have no co-ordinations in Mathematics. School librarians who are involved in co-ordinations typically have between 1 and 5 co-ordinations per year, with a small number of school libraries with over 20 coordinations per year.

Compared to the number of co-operations and co-ordinations, the number of collaborations is low, as shown in Table 1. $60 \%$ of the school librarians do not engage in formal collaborations to integrate information literacy into the English curriculum, and considerably higher percentages in the other curriculum areas identified in this study. 
Table 1: Collaborations Across Curriculum Areas

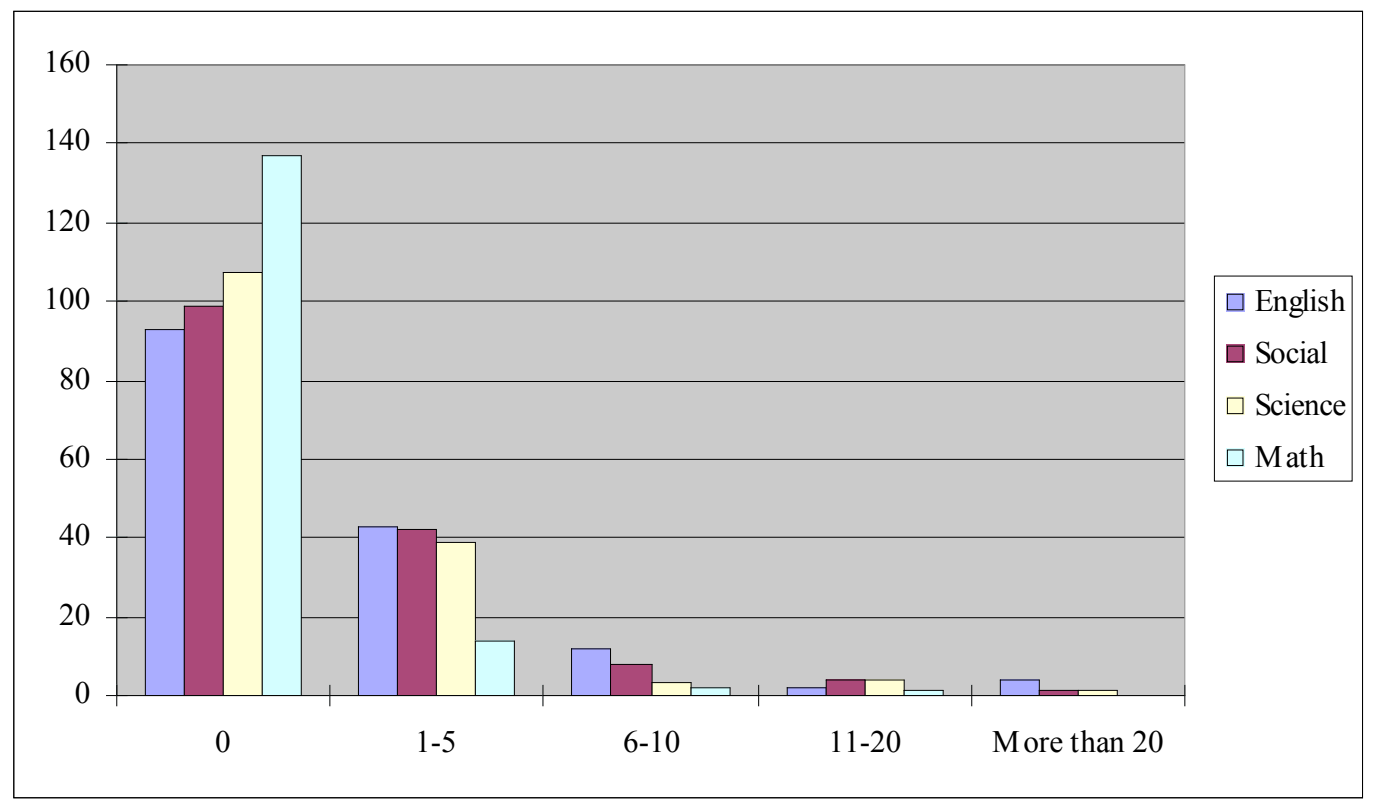

Table 1 also indicates that there is a small group of school librarians who do engage in an extensive number of formal collaborations. The highest number of collaborations take place where there is a full time, certified school librarian who operates a library program based on flexible scheduling. School libraries where very low levels of co-operations, coordinations and collaborations take place are typically elementary schools without a certified school librarian or who do not have a full time support staff in the building. Given that both Delaware's statement of standards, and AASL national standards, speak to the professional role of school librarians providing collaborative and integrated instruction in relation to information literacy development, this professional role is not taking place in a widespread and sustained way in Delaware.

\section{Participation In School Life}

School librarians in Delaware actively participate in many different school and community forums. There is some variation, however, according to type of activity and school type (elementary, middle and high). Faculty meetings are the primary means that school librarians use to communicate about library resources and learning initiatives. $73 \%$ of the school librarians speak at faculty meetings. In addition, $62.3 \%$ of school librarians engage in regular $48 \%$ of school librarians are involved in the provision of professional development on information literacy in their school communities. meetings with key school personnel. This is more predominant in the middle and high schools. Other means of communication, such as department meetings and grade level meetings are not heavily utilized. 54\% of school librarians do not share aspects of their library's programs (either instruction, resourcing or reading) to parent / community organizations. Overall there is low participation in district curriculum committees and school improvement plan committees (14\% and 31\% respectively). The school librarians typically participate in at least one professional development activity each year, and these extend into a range of curriculum areas. Participation in reading association conferences, state library conferences, and national school library conferences is very low. 


\section{Information Literacy Instruction}

Delaware School librarians engage in a range of information literacy instruction initiatives. These are shown in Tables 2 (Scope of Participation in Information Literacy Instruction) and Table 3 (Scope of Participation by School Type):

\section{Table 2: Scope of Participation in Information Literacy Instruction}

\begin{tabular}{|c|c|c|c|}
\hline $\begin{array}{r}\text { Dimensions of Information } \\
\text { Literacy Instruction }\end{array}$ & & $\mathbf{N}$ & $\%$ \\
\hline Knowing about the school library. & & 145 & $94 \%$ \\
\hline $\begin{array}{r}\text { Understand the different strategies in } \\
\text { doing effective research. }\end{array}$ & & 118 & $77 \%$ \\
\hline $\begin{array}{l}\text { Knowing about different sources and } \\
\text { formats of information. }\end{array}$ & & 146 & $95 \%$ \\
\hline $\begin{array}{l}\text { Knowing how to use the different } \\
\text { sources and formats of information. }\end{array}$ & & 120 & $78 \%$ \\
\hline $\begin{array}{l}\text { Identifying main ideas in information } \\
\text { sources (analyzing information). }\end{array}$ & & 91 & $59 \%$ \\
\hline $\begin{array}{l}\text { Sorting and organizing ideas } \\
\text { (Synthesizing information). }\end{array}$ & & 84 & $55 \%$ \\
\hline Evaluating information for quality. & 5 & 109 & $71 \%$ \\
\hline $\begin{array}{l}\text { Using information ethically (e.g. } \\
\text { Plagiarism, citation, bibliography). }\end{array}$ & & 117 & $76 \%$ \\
\hline Creating information products. & 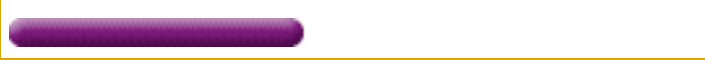 & 66 & $43 \%$ \\
\hline $\begin{array}{r}\text { Communicating/presenting ideas } \\
\text { (orally and/or in writing). }\end{array}$ & & 83 & $54 \%$ \\
\hline $\begin{array}{l}\text { Accommodating differentiated } \\
\text { learning styles and abilities. }\end{array}$ & 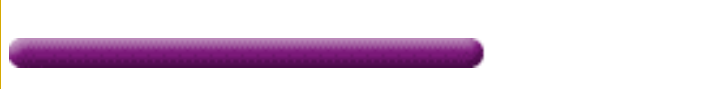 & 107 & $69 \%$ \\
\hline
\end{tabular}

Table 3: Scope of Participation by School Type

\begin{tabular}{|l|c|c|c|}
\hline Dimension & Elementary & Middle & High \\
\hline \multicolumn{1}{|c|}{ Knowing about the school library. } & $95.6 \%$ & $93.5 \%$ & $90.0 \%$ \\
\hline $\begin{array}{l}\text { Understand the different strategies in } \\
\text { doing effective research. }\end{array}$ & $70.3 \%$ & $80.6 \%$ & $90.0 \%$ \\
\hline $\begin{array}{l}\text { Knowing about different sources and } \\
\text { formats of information. }\end{array}$ & $91.2 \%$ & $100 \%$ & $100 \%$ \\
\hline $\begin{array}{l}\text { Knowing how to use the different } \\
\text { sources and formats of information. }\end{array}$ & $70.3 \%$ & $87.1 \%$ & $90 \%$ \\
\hline $\begin{array}{l}\text { Identifying main ideas in information } \\
\text { sources (analyzing information). }\end{array}$ & $56.0 \%$ & $61.3 \%$ & $66.7 \%$ \\
\hline $\begin{array}{l}\text { Sorting and organizing ideas } \\
\text { (Synthesizing information). }\end{array}$ & $53.8 \%$ & $58.1 \%$ & $53.3 \%$ \\
\hline \multicolumn{1}{|c|}{ Evaluating information for quality. } & $59.3 \%$ & $83.9 \%$ & $93.3 \%$ \\
\hline $\begin{array}{l}\text { Using information ethically (e.g. } \\
\text { Plagiarism, citation, bibliography). }\end{array}$ & $67.0 \%$ & $96.8 \%$ & $83.3 \%$ \\
\hline
\end{tabular}




\begin{tabular}{|c|c|c|c|}
\hline Creating information products. & $38.5 \%$ & $54.8 \%$ & $43.3 \%$ \\
\hline $\begin{array}{l}\text { Communicating/presenting ideas (orally } \\
\text { and/or in writing). }\end{array}$ & $57.1 \%$ & $54.8 \%$ & $43.3 \%$ \\
\hline $\begin{array}{l}\text { Accommodating differentiated learning } \\
\text { styles and abilities. }\end{array}$ & $72.5 \%$ & $67.7 \%$ & $60.0 \%$ \\
\hline
\end{tabular}

As shown in Tables 2 and 3, this instruction typically centers on knowing about the school library, different sources and formats and the different strategies in doing effective research, learning how to use resources, and evaluating information. Given the low levels of co-ordinations and collaborations, these would appear to primarily take place in isolation in the school library, and not optimally as part of instructional partnerships with classroom teachers. Despite issues with staffing in the elementary schools, school librarians where available contributed substantially to this instruction.

The data also suggest that the focus of information literacy instruction centers on sources - knowing the library, knowing the different formats and sources, knowing how to use them, and knowing how to determine their quality and appropriateness. This is an important foundation for developing information literate students. However, the data raise some concerns. Information literacy instructions and interventions that focus on the holistic experience of learners in the process of constructing new understandings and meanings of their curriculum content were not strongly represented in the data. Negligible mention was made of the information literacy skills that relate to learners developing deep knowledge and deep understanding of their curriculum topics: skills such as analyzing the information to identify important and needed components, interpreting the information against existing knowledge as well as other sources, identifying and understanding the key ideas, organizing the salient ideas into some meaningful structure to create a personal understanding, critiquing multiple viewpoints and opposing ideas, structuring arguments and formulating conclusions; creating information products that best represent the new knowledge gained, and developing communication processes to effectively share new understandings. While some of the school librarians provided some indication that they were moving beyond "source orientations" to "knowledge orientations", this more holistic view of information literacy - involving access AND use of information was not pervasive.

\section{Information Technology Instruction}

Table 4 shows that the school librarians undertake instructional activities to help students engage with information technology in efficient and productive ways.

Table 4: Instructional Activities for Effective Use of Information Technology

\begin{tabular}{|c|c|c|c|}
\hline Dimension & & $\mathbf{N}$ & $\%$ \\
\hline $\begin{array}{l}\text { Searching strategies for the World } \\
\text { Wide Web. }\end{array}$ & & 124 & $81 \%$ \\
\hline Evaluating the quality of websites. & 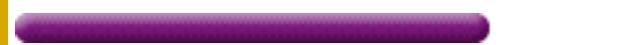 & 101 & $66 \%$ \\
\hline $\begin{array}{r}\text { Using computer programs to do } \\
\text { school work (i.e. Power Point, } \\
\text { Excel). }\end{array}$ & $=$ & 76 & $49 \%$ \\
\hline
\end{tabular}




\begin{tabular}{|c|c|c|c|}
\hline $\begin{array}{r}\text { Using UDLibSearch, other electronic } \\
\text { databases/library catalogs and } \\
\text { directories. }\end{array}$ & & 113 & $73 \%$ \\
\hline $\begin{array}{r}\text { Teaching about the ethical use of the } \\
\text { internet. }\end{array}$ & & 103 & $67 \%$ \\
\hline $\begin{array}{r}\text { Integrating technology in the content } \\
\text { areas. }\end{array}$ & 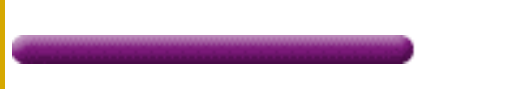 & 86 & $56 \%$ \\
\hline
\end{tabular}

Most typically this includes searching strategies for the world wide web, using UDLib/Search and other electronic databases, evaluating web sites, and teaching about the ethical use of the internet. This takes place more widely in middle and high schools. Given the low levels of co-ordinations and collaborations, these too appear to primarily take place in isolation in the school library, and not as part of instructional partnerships with classroom teachers.

\section{Reading/writing initiatives}

Given that school libraries have a long tradition in fostering in students a love of reading, and the development of self-motivated and competent readers, the survey sought to identify the range of reading/writing initiatives that school librarians have undertaken. School librarians do engage in a wide range of activities to promote reading across the school. The number of percentage of school librarians engaging in these various activities is shown in Table 5:

\section{Table 5: Frequency of Reading / Writing Initiatives of School Librarians}

\begin{tabular}{|c|c|c|}
\hline Dimension & $\mathbf{N}$ & $\%$ \\
\hline Book talks to promote literature for self-selected & 120 & $78 \%$ \\
\hline Book talks to promote trade books (non text & 80 & $52 \%$ \\
\hline Author visit. & 29 & $19 \%$ \\
\hline $\begin{array}{r}\text { Literature discussion groups, where students } \\
\text { share ideas and discuss their reading. }\end{array}$ & 46 & $30 \%$ \\
\hline $\begin{array}{l}\text { Literature } \\
\text { displays. }\end{array}$ & 130 & $84 \%$ \\
\hline $\begin{array}{r}\text { Creative writing activities related to } \\
\text { literature. }\end{array}$ & 57 & $37 \%$ \\
\hline $\begin{array}{l}\text { Book } \\
\text { Clubs. }\end{array}$ & 34 & $22 \%$ \\
\hline $\begin{array}{l}\text { Story } \\
\text { telling. }\end{array}$ & 67 & $44 \%$ \\
\hline $\begin{array}{r}\text { Promotion of reading programs at public } \\
\text { libraries and/or other venues. }\end{array}$ & 80 & $52 \%$ \\
\hline $\begin{array}{r}\text { Other reading incentive programs such as } \\
\text { Accelerated Reader. }\end{array}$ & 95 & $62 \%$ \\
\hline
\end{tabular}


Table 5 shows that a high number of school librarians present literature displays to encourage reading, and engage in book talks to promote literature. Half of the school librarians in Delaware promote informational resources to students, and promote reading programs taking place at public libraries and / or other venues, and almost two-thirds work with reading incentive programs such as Accelerated Reader. Additional activities included: Delaware Reads About program; Book fairs; Reading celebrations and festivals, such as Dr. Seuss Day, Festival of Words, "February, I Love to Read" promotion Participation in Summer Reading Programs through public libraries, Providing advice to teachers on reading initiatives, Contests, such as poetry contest, Mystery Reader contests and Triva type activities; Reading encouragement programs, such as provision of reading lists, "Battle of the Books", 100 Day Book Challenge, High Flying Readers, Delaware Diamonds, read aloud programs, Celebrity readers; Creative programs: acting out stories, puppet shows, Coffeehouses for creative writing; Promoting access to books: visits to bookstores, Public Library Card Drive for students; and distributing books to students who had none at home.

Two concerns emerge out of this data. First, reading enrichment programs were more pervasive in the elementary school, and declined in frequency through middle school and high school. There may be a number of possible reasons for this, such as the focus on informational resources to meet curriculum demands, and the perceived notion that such activities are for younger children. However, the reduction of such activities conveys a perception that high school libraries are not about reading for enjoyment and pleasure, and this is a serious issue, especially in fostering an ongoing love of reading for pleasure after schooling. Second, the reading activities that were most typically undertaken were primarily passive activities. Book display, book promotions, promotion of reading programs may, but do not necessarily engage students. Those reading initiatives that foster active engagement, discussion, creative output, such a discussion groups, literature circles, book raps, had much lower rates of school librarian involvement.

The school librarians identified a range of learning outcomes enabled by the school library. Based on responses from 144 school librarians, the data suggest that school libraries in Delaware play a role in helping students learn in their curriculum areas in five predominant ways. These are identified in Table 6, and supported with illustrative examples.

Table 6: Significant Learning Outcomes Enabled by the School Library

\begin{tabular}{|l|c|l|}
\hline Outcome & $\mathbf{N}$ & \multicolumn{1}{c|}{ Examples } \\
\hline $\begin{array}{l}\text { Mastery of research } \\
\text { processes, and research } \\
\text { skills involved in locating } \\
\text { and selecting sources, } \\
\text { organizing, and evaluating } \\
\text { information, and compiling } \\
\text { information }\end{array}$ & 61 & $\begin{array}{l}\text { "Information skills. Finding and evaluating good sources of } \\
\text { information" } \\
\text { "Students understand the process of research and follow } \\
\text { steps in order to achieve success" } \\
\text { "Mastery of research process specific to curriculum content } \\
\text { and bibliographic citation of sources;" } \\
\text { "Students are capable and confident researchers." }\end{array}$ \\
\hline $\begin{array}{l}\text { Improved reading skills, } \\
\text { more interest in reading }\end{array}$ & 58 & $\begin{array}{l}\text { "Increased outside reading, children coming daily for new } \\
\text { books" }\end{array}$ \\
\hline
\end{tabular}




\begin{tabular}{|l|l|l|}
\hline & & $\begin{array}{l}\text { "We feel that we made changes in attitude, interest, and } \\
\text { motivation in selecting appropriate books to improve } \\
\text { reading skills through Accelerated Reader and instruction." } \\
\text { "Some students have become more interested in literature } \\
\text { and have become more motivated to read books that they } \\
\text { would not usually select". }\end{array}$ \\
\hline $\begin{array}{l}\text { Mastery of information } \\
\text { technology skills- internet, } \\
\text { online catalog, databases, } \\
\text { searching UDLib, learning } \\
\text { new presentation formats }\end{array}$ & 34 & $\begin{array}{l}\text { "students have better understanding of web use (safety, } \\
\text { quality)" } \\
\text { "Students learned to use on-line public access catalog } \\
\text { independently. Students practiced using a research "path." } \\
\text { "Presented the characteristics of poetry using Power Point," } \\
\text { "Students used Microsoft Publisher to publish their stories } \\
\text { and they were displayed at a parent night" }\end{array}$ \\
\hline $\begin{array}{l}\text { Change in attitude, interest, } \\
\text { and motivation- positive } \\
\text { attitude to visit library, } \\
\text { increase interest, } \\
\text { engagement in library } \\
\text { activities }\end{array}$ & 24 & $\begin{array}{l}\text { "I am pleased with the change in attitude, interest in the our } \\
\text { school library." } \\
\text { "Children have shown positive attitudes when visiting the } \\
\text { library. The atmosphere is always charged with good } \\
\text { comments and reactions by all who visit" } \\
\text { "high interest in library and books, motivated readers from } \\
\text { displays and activities" }\end{array}$ \\
\hline $\begin{array}{l}\text { Learning of specific } \\
\text { curriculum content }\end{array}$ & 7 & $\begin{array}{l}\text { "Students can identify and describe all the vocabulary in our } \\
\text { Curriculum guide" } \\
\text { "mastery of curriculum" } \\
\text { "Students are able to differentiate between continents, } \\
\text { countries, and cities" } \\
\text { "curriculum based information" }\end{array}$ \\
\hline
\end{tabular}

$39.6 \%$ of the school librarians indicate that their school library helps students become effective researchers, and develops in them a range of skills in locating and selecting sources, organizing and evaluating information, and compiling information. 37.7\% indicate that their school library helps improve reading sills and helps students develop greater interest in and motivation for reading. $22.1 \%$ that their school library helps students develop a range of technology skills related to using the internet effectively, and searching online databases and catalogs. $15.6 \%$ of indicate that their school library helps students develop positive attitudes to libraries. Very few school librarians (4.5\%) articulate learning outcomes linked to curriculum standards and goals.

Two observations can be made of this analysis. First, while it is encouraging that school librarians articulated improvements in terms of reading, information literacy, use of information technology, and improved attitudes towards the library, very few could articulate learning outcomes in relation to the students' development of deep knowledge and deep understanding of content areas. They appeared to have difficulty articulating the outcomes of library initiatives in terms of curriculum standards and goals. Second, many school librarians had difficulty focusing on student outcomes, rather, many school librarians articulated (often at length) what they did, identifying instructional inputs and processes, rather than clarifying outcomes from the perspective of the students.

\section{Library Administration}

All school librarians are involved in an extensive range of library administration responsibilities: selection, ordering and processing of resources, supervision of staff and volunteers, as well as technical equipment maintenance, and other school duties. For the majority of school librarians, this takes place on a daily or weekly basis. These are time 
consuming responsibilities, and clearly school librarians invest a considerable amount of time in these responsibilities. Given the time commitments to perform the range of administrative, supervisory, equipment maintenance, and duty responsibilities, this may well contribute to explaining the low levels of co-operations, co-ordinations and collaborations that the study identifies. A possible contributor to this may be the fact that $40 \%$ of school libraries are operating on flexible scheduling of classes.

\section{Information Resources and Information Technology: A Brief Snapshot}

At the time of the study (2005) there were approximately 1.6 million materials housed in Delaware's school libraries, with an average of 11,500 per school $(10,400$ for elementary schools, 12,500 for middle schools and 13,500 for high schools). The average number of materials per student at this time was 15.36 . Of these materials, approximately 1.37 million were books. This is $87.5 \%$ of the total materials. The average number of books per student was 12.65. While a number of schools had above this average, this figure is well below the minimum resource recommendation of 15 currently useful volumes per student presented as established in "Standards for School Library Media Centers: Delaware Public Schools". $37 \%$ of Delaware's school libraries did not meet this minimum resource recommendation. Only $38 \%$ of Delaware's school libraries have good or exemplary resource levels (that is, above 20 currently useful volumes per student [good], and 25 useful volumes per students [exemplary]. Participation in interlibrary lending was low. Over half of Delaware's school libraries have annual budget allocations below $\$ 6,000$, and $30 \%$ of school libraries experienced budget decreases from the previous school year.

At the time of the study, the average number of magazines in school libraries was 21 (13 for elementary schools [minimum recommendation is 15-20], 23 for middle schools [minimum recommendation is 45-55]; and 45 for high schools [minimum recommendation is 55-70]). The average number of newspapers in school libraries was 1.4. Overall, the majority of Delaware's school libraries fell below the minimum recommendations for books, magazines and newspapers. $40 \%$ of school library catalogs were searchable via the internet, providing opportunities for students in some schools to access the school library independently after school time. The average number of computers in the school libraries available for internet access was 15 (10 in elementary schools, 20 in middle schools, and 29 in high schools). 56 school libraries had web sites.

\section{So What, And Where To Next?}

The findings indicate that those school libraries that are strongly integrated into the learning fabric of the school and which contribute to student learning outcomes - have a common set of characteristics including:

- a state certified, full time school librarian in the building;

- the availability of support staff who free the school librarian to undertake instructional initiatives and reading literacy initiatives;

- flexible scheduling so that school librarians and classroom teachers can engage in collaborative planning and delivery of information literacy instruction;

- an active instructional program of information literacy targeted towards learning curriculum content and skills;

- a school library that meets resource recommendations of 15-20 books per child;

- the provision of professional development on information literacy and technology literacies to the teaching faculty; 
- a budget allocation of \$12-\$15 per student per year to ensure currency and vitality of the information base;

- A strong networked information technology infrastructure that facilitates access to and use of information resources in an out of the school.

However, the findings also show that while Delaware's school libraries are making some (and variable) progress in reaching infrastructure standards and instructional goals there are common shortcomings in the provision of infrastructure - resources, full time staffing - as well as collaborative instructional opportunities to work with classroom teachers targeted to meeting curriculum standards and demonstrating learning outcomes that go beyond mastery of a basic set of information competencies. Given the low level of articulating outcomes of the school library's program, the findings indicate that there are some significant communication issues and missed opportunities that both school librarians and school leaders in Delaware need to reflect on and address. In addition, the findings also suggest opportunities to rethink reading and literacy initiatives, not just in terms of building motivation and engagement with reading, but also to link with state and national reading initiatives that focus on improving reading achievement, as well as reading for comprehension.

These challenges became the basis for key recommendations made to the Task Force, and a starting point for responding to the evidence and implementing a program of continuous improvement and capacity building of school libraries in Delaware. Key recommendations included:

- developing a stronger evidenced-based practice approach to school library programs targeted to measuring and demonstrating the school library's contribution to student learning programs;

- developing stronger collaborative instructional programs targeted to meeting the knowledge and skills outcomes embedded in Delaware's curriculum standards rather than focusing on simplistic information competencies;

- with particular emphasis on reading and literacy development, developing skills of engaging with school, district and state reading data in order to identify achievement gaps, learning needs, and to translate these needs into instructional and service programs through the school library and measure evidence of progress;

- developing negotiating school and district improvement plans that engage the school library in a direct and deliberate process of identifying school achievement gaps and developing evidence-based programs to contribute to closing achievement gaps;

- developing an integrated professional development program of school librarians, school communities and educational leaders to work together to ensure that high levels of student achievement take place.

\section{Part 2: From Evidence to Action}

Based in the challenges identified above, this section will briefly outline the processes and programs currently being undertaken in Delaware to build capacity and continuous improvement of school libraries. This has centered on three sustained programs of professional action, and which has engaged multiple experts at state and regional level working together to provide an experience-based and evidence-based program of development and implementation. 
The underpinning practice orientation that has framed this program is evidence-based practice. Evidence-based practice, as an approach to professional practice in school libraries, systematically engages research-derived evidence, school librarian-observed evidence and user-reported evidence in iterative processes of decision making, development and continuous improvement to achieve the school's mission and goals. At the heart of evidencebased practice are the students' information-to-knowledge experience, achievement, quality learning, and quality teaching. Evidence-based school librarianship is founded on the conscientious interpretation and integration of research-derived evidence to shape and direct professional practice. Its day-by-day practice meshes professional wisdom, reflective experience and understanding of user needs with the judicious use of research-derived evidence to make judgments and decisions about how to deliver the instructional and service roles of the school library to meet the goals of the school (Todd, 2007). Accordingly, the development program initiated in Delaware has focused on evidence-based decision making though engaging with research evidence, evidence existing in the school and state, and outcomes-based evidence. It has given explicit attention to engaging with multiple sources of evidence: data from the state-based research, the research literature of the field, data available through the Department of Education focusing on student achievement, other school-based data, as well as school library data generated through library systems and services.

To date, three four-day mini-courses have been developed and implemented (in progress), targeted to developing collaborative instructional capacity, data-driven planning and decision making, establishing systematic measures for documenting learning outcomes which become part of the cycle of continuous improvement. Each of these programs have involved school librarians working in collaborative partnerships with district and school classroom teachers, reading and literacy experts, and curriculum leaders in the key learning areas of the Department of Education. A key expectation of the program has been that school librarians will facilitate training in their school districts. Each of the mini-courses is briefly described here. Their development emerged out of considerable engagement in the research data, establishing priorities and negotiating the developmental processes.

\section{Mini-Course 1: School Librarians and School Improvement}

This course seeks to provide school librarians with an understanding of the processes involved in evidence-based practice, knowledge of the range of achievement and general school data available in and beyond Delaware to underpin evidence-based practice; skills and strategies on how to interrogate and analyze this data to inform school improvement efforts in Delaware, how to use this data in making decisions for school improvement efforts, develop library interventions and measure the impacts, and how to engage with school-based improvement planning processes.

Participants are involved in creating a library improvement plan that could be incorporated into the school's improvement plan, with explicit attention to data-driven needs analysis, design of instructional and service interventions, and design of outcome measures to establish efficacy of improvement processes. The improvement plan has the following components:

- Improvement Goal: (How would we like to see student achievement improve on the high priority, grade level standards over the next one, two, or three years?) How does this relate to school goals and school improvement goals and processes?

- Supportive Data: (Current Achievement): Which students are and are not able to 
demonstrate (at proficient or higher levels) the knowledge and skills described by what high priority, grade-level standards and/or related benchmarks? What data were used to describe current achievement? Why is current practice not effective for these students? What may be other explanations for why the identified students are not learning?

- Improvement strategies. Given the explanations and the data, what changes do we need to make in current practice - in the day-to-day work of students and teachers, to produce the desired outcomes? What are the research-based instructional strategies that can be implemented, and why are these appropriate?

- Measurable Objectives: What will be the change for students to validate our success? How will we track our progress in implementing the changes in practices that we have identified as our principal strategies for improving student achievement?

- Targeted Staff: Who will provide leadership and be responsible for the implementation of the activity?

- Decision: Do you believe that, if the strategy you have described above is wellimplemented, it would actually enable the targeted students to achieve the inferred improvement goal? Explain why you think the strategy will either enable or not enable the targeted students to achieve the inferred improvement goal.

Mini-Course 2: Unpacking the Standards in the Library.

This program involves Curriculum Associates of the Department of Education, district content specialists, and classroom teachers working in an evidence-based collaborative partnership. The collaborative teams:

- build an understanding of current research in relation to constructivist learning; student information seeking and learning in complex and diverse information environments;

- develop an understanding of the principles of guided inquiry as a pedagogical framework for constructing meaningful learning through the school library based on the Guided Inquiry framework of Kuhlthau (2007) and CISSL;

- engage in an in-depth analysis of the new Delaware Recommended Curriculum (DRC) in ELA, Math, Science and Social Studies to identify content standards and AASL learning standards (2007) that lend themselves to collaborative studentcentered inquiry through the school library;

- work with Delaware curriculum experts to design integrated and collaborative guided inquiry units based on Delaware standards. These exemplars of collaborative curriculum inquiry units incorporate evidence-based measures to chart learning outcomes and are highlighed on DRC website for all classroom teachers and school librarians.

A condensed version of the Delaware Curriculum Unit Template that guided the collaborative planning process is provided here. It has been developed by the Department of Education I Delaware to facilitate integrated and collaborative instruction.

\section{Delaware Curriculum Unit Template}

Preface: This unit has been created as a model for teachers in their designing or redesigning of course curricula. It is by no means intended to be inclusive; rather it is meant to be a springboard for a teacher's thoughts and creativity. The information we have included represents one possibility for developing a unit based on the Delaware content standards and the Backward Design framework and philosophy, and 
Universal Design for Learning (UDL) principles. When a unit is universally-designed, its goals, methods, materials, and assessments take into consideration the full range of diversity in our classrooms and provide the means for all students to participate and achieve.

\begin{tabular}{ll|} 
Subject/Topic Area: & Grade Level(s): \\
Searchable Key Words: & District: \\
Designed By: & \\
Time Frame: & Date: \\
Reviewed by: & \\
\hline
\end{tabular}

Brief Summary of Unit (This should include a brief unit summary including a description of unit goals, rationale for the approach taken, and where it appears in the course of study.)

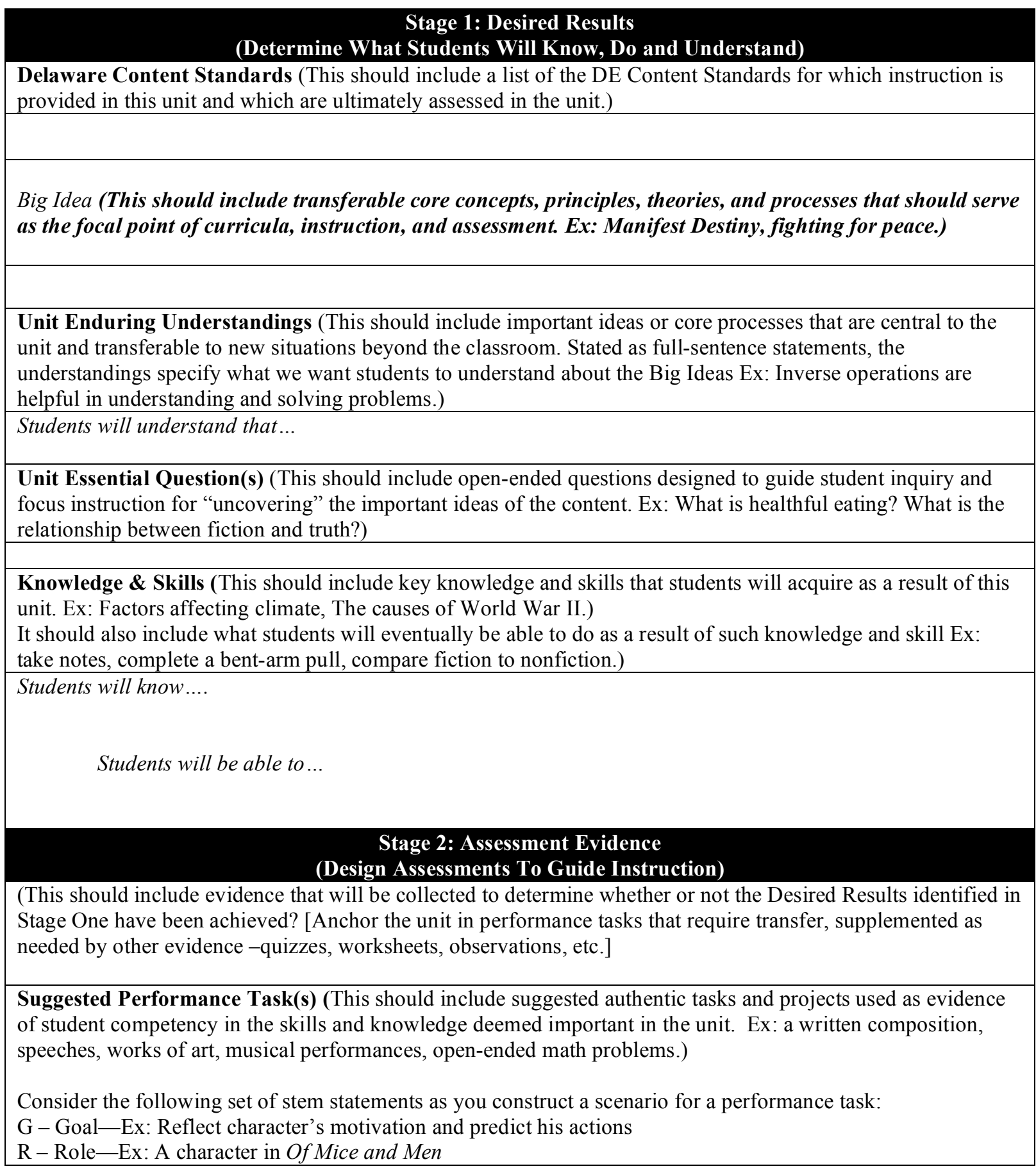


A - Audience-Ex: A family member or close friend

S - Situation-Ex: Creating a scrapbook chronicling a character's life, real and inferred

$\mathrm{P}$ - Product, Performance, and Purpose-Ex: Scrapbook

S - Standards and Criteria for Success_-Ex: Your scrapbook should include all components on included rubric

Rubrics/checklists for Performance Tasks (This should include holistic or analytic-trait rubrics used as a scoring guide to evaluate student products or performances.)

Other Evidence (This could include tests, quizzes, prompts, student work samples, and observations used to collect diverse evidence of student understanding.)

Student Self-Assessment and Reflection (This should include opportunities for students to monitor their own learning. Ex: reflection journals, learning logs, pre- and post-tests, editing own work.)

\section{(Design Learning Activities To Align with Goals and Assessments)}

Key learning events needed to achieve unit goals

(This should include instructional activities and learning experiences needed to achieve the desired results (Stage 1) as reflected in the assessment evidence to be gathered (Stage 2).

The acronym WHERETO summarizes key elements to consider when designing an effective and engaging learning plan for ALL students.

$\mathrm{W}$ - Help the students know $\underline{W}$ here the unit is going and What is expected? Help the teachers know

Where the students are coming from (prior knowledge, interests)

$\mathrm{H}-$ Hook ALL students and $\underline{H o l d}$ their interest?

E - Equip students, help them Experience the key ideas and Explore the issues?

$\mathrm{R}$ - Provide opportunities to Rethink and Revise their understandings and work?

E - Allow ALL students to Evaluate their work and its implications?

$\mathrm{T}-\mathrm{Be}$ Tailored (personalized) to the different needs, interests, and abilities of ALL learners?

$\mathrm{O}-\mathrm{Be}$ Organized to maximize initial and sustained engagement as well as effective learning?

\section{Did you consider the following unit design principles?}

IP - International education perspective

IL - Information Literacy

WR - Workplace readiness $/ 21^{\text {st }}$ century skills

FA - Formative assessment, used to check for understanding

$T L-$ Technology Literacy

Resources \& Teaching Tips (Consider the two questions below when completing this section.)

What text/print/media/kit/web resources best support this unit?

What tips to teachers of the unit can you offer about likely rough spots/student misunderstandings and performance weaknesses, and how to troubleshoot those issues?

Differentiation (This should include a list or description of ways that you will differentiate instruction according to students' needs. This can include any curricular adaptations/accommodations that are needed to meet the needs of ALL students, including students with disabilities. Ex: using reading materials at varying readability levels, putting text materials on tape, using spelling or vocabulary lists at readiness levels of students, meeting with small groups to re-teach an idea or skill for struggling learners, or to extend the thinking or skills of advanced learners.)

\section{Technology Integration}

Content Connections 


\section{Mini-Course 3: Literacy and School Improvement.}

This course seeks to engage school librarians with reading/literacy specialist partners, in the development of initiatives targeted to reducing state achievement gaps in relation to reading and literacy. Lead by the Delaware Department of Education's Curriculum Associate for English Language Arts (which encompasses reading and literacy), the school librarian-reading specialist teams:

- examine scientifically based research and writing strategies presented in a diverse body of literature;

- examine and interrogate reading achievement data of Delaware meshed with data from the Delaware school library studies to establish achievement gaps that have potential to be closed through a range of school library interventions;

- focus on measurable evidence to develop a student centered survey to collect evidence on their knowledge and ability in articulating the standards and their motivation towards reading;

- investigate student centered active interventions based on their survey's results and the findings and recommendations of the Delaware Library Study;

- develop a collaborative library-based improvement plans which targeted Delaware Grade-Level Expectations in ELA and AASL Learning Standards (AASL 2007), including processes and strategies to systematically measure the impacts;

- initiate a Community of Practice for continuous school improvement in Reading and Writing.

These three mini-courses are ambitious, and evaluative data on their impact are currently being collected as the courses are implemented. They highlight developing a stronger evidenced-based practice approach to school library programs targeted to measuring and demonstrating the school library's contribution to student learning programs. They have been constructed on several key principles: engaging, utilizing and modeling shared expertise across multiple sectors of the educational arena - school librarians, state curriculum leaders, district experts, school improvement personnel, and class room teachers committed to building capacity of school libraries and developing collaborative processes; developing skills of engaging with school, district and state research and achievement data in order to identify achievement gaps, learning needs, and to translate these needs into instructional and service programs through the school library and measure evidence of progress; and clearly linking any improvement planning and capacity building processes to school-wide processes and goals. In essence, school librarians have begun a process of being directly engaged in learning outcomes, engaged in collaborative processes of identifying achievement gaps, building their professional practice on an evidence-based approach, and taking ownership responsibility for the developmental needs of students, which in turn engages them more deliberately and overtly in connecting the school library to what schools are about.

A pervasive belief underpinning the improvement program described here is that school librarians must take action - action that is informed by systematic research, guided by experience and wisdom, engages strategically and carefully with evidence, and which creates evidence for continuous improvement and program development, and for building active support for school librarians and school libraries. Robert F Kennedy, in the Day of Affirmation address delivered at the University of Capetown, South Africa, on June 6, 1966, made this statement: "Few will have the greatness to bend history; but each of us can work to change a small portion of events, and in the total of all those acts will be written the history of this generation" 


\section{References}

Eldredge, J. (2000). Evidence-Based Librarianship: An Overview. Bulletin of the Medical Library Association. 2000 October; 88(4): 289-302.

Gore, J., Griffiths, T., \& Ladwig, J. (2002). Exploring 'productive pedagogy' as a framework for teacher learning, Paper prepared for presentation at the Annual Meeting of the Australian Association for Research in Education, Brisbane, December 2-5, 2002. Retrieved November 4, 2004, from: http://www.aare.edu.au/02pap/gor02267.htm

Harris, A. \& Lambert, L. (2003). Building leadership capacity for school improvement. Open University Press, London.

Kennedy, R. (1966). (Kennedy, 1966). As recorded in: Congressional Record, June 6, 1966, vol. $112, p .12430$.

Kuhlthau, C., Maniotes, L. \& Caspari, A. (2007). Guided inquiry: Learning in the 21st century. Libraries Unlimited, Westport, Conn.

Noah, C. \& Brickman, A. (2004). Capacity building for libraries. Public Libraries, March/April: 102-107.

Scholastic, Inc. (2008). School Libraries Work! Scholastic Research \& Results Series, No.3. Scholastic Library Publishing, New York.

Slavin, R. (2008). What Works? Issues in Synthesizing Educational Program Evaluations. Educational Leadership. 37(1), 5-14.

Todd, R. J. (2005). Report of the Delaware school library study. New Brunswick, NJ.: Center for International Scholarship in School Libraries.

Available at: http://www2.lib.udel.edu/taskforce/study/phasetwo.pdf

Todd, R. (2007). Evidence Based Practice and School Libraries: From Advocacy to Action in Harada, V. \& Hughes-Hassell, S. (eds.). Principles \& Practice Volume 3: School Reform and the School Library Media Specialist, Libraries Unlimited, p. 57-78

Todd, R. \& Kuhlthau, C. (2005). Student learning through Ohio school libraries, Part 1: How effective school libraries help students. School Libraries Worldwide, 11(1), 89-110.

\section{Biographical Notes}

Dr Ross J Todd is Associate Professor in the School of Communication, Information and Library Studies at Rutgers, the State University of New Jersey. He is Director of the Center for International Scholarship in School Libraries (CISSL). Current research focuses on three key themes: examining the impact of implementing an inquiry-based approach to learning centering on the Information Search Process developed by Professor Carol Kuhlthau on student learning outcomes; understanding more fully the cognitive dynamics of adolescent information seeking and use, with particular emphasis on changing information intents and 
patterns of knowledge construction; and developing an evidence-based practice framework for school librarians.

\section{Acknowledgement}

This paper acknowledges the expertise of Education Associates from Delaware Department of Education: Denise DiSabatino Allen (Library/Media/Technology), Malik Stewart (School Improvement) and Juley Harper (English Language Arts) who have contributed substantially to the professional program documented here. It also acknowledges the ongoing leadership of the Governor's Task Force on School Libraries and its vision and actions to improving school libraries in Delaware.

\section{Statement of Originality}

This statement certifies that the paper above is based upon original research undertaken by the author and that the paper was conceived and written by the author(s) alone and has not been published elsewhere. All information and ideas from others is referenced. 